\title{
The Impact of Industry Variables on Company’s Performance
}

\author{
Dr. Enida Pulaj (Brakaj) \\ University of Vlora, Department of Business \\ Email: enidapulaj@yahoo.com; enida.pulaj@univlora.edu.al
}

\section{Doi:10.5901/mjss.2017.v8n1p202}

\begin{abstract}
Everywhere, in the business world and not only, we speak about the competitiveness. And while talking about this concept, it seems appropriate to explain what the competitiveness is and how it influences the organizational performance. Nowadays, there has been a growing intensity of competition in all business areas and this has resulted in a greater attention to analyze the competitive behavior under environmental dynamics and complexity. The industry is the "arena" where starts and applies every company's activity. Usually, facing the high level of competition, it is necessary to study all the variables which influence the organization in order to achieve goals such as: the profitability and ensuring organization's longevity. The purpose of this paper is to examine the relationship between industry forces and organizational performance to test the applicability of Porter's model explaining the differences in the performance of construction companies. The methodology used is in the function of links between variables that characterize the industry and the realized performance, expressed through overall performance. The primary data collection was conducted through a questionnaire. Besides the demographic characteristics of the sample, the questionnaire as well aims to collect information on a high number of variables. Geographically, the companies participated by completed the questionnaire, were performing their business activity in Vlora region (such as Vlora city, Orikum and Himara), covering areas where construction sectors had the major development, including urban and coastline areas. The processing data collected via questionnaire shows that the construction industry is characterized by a high level of competitiveness and market fragmentation. Through the empirical analysis of competitive forces, the study contributes to the specific orientation that investors and managers should have when they face a high rivalry among companies
\end{abstract}

Keywords: industry, competitiveness, organizational performance, construction industry

\section{Introduction}

The industry is "arena" where the competition takes place. In this dynamic and complex environment, there are a number of factors which both of the competitive forces structure the industry, determine the intensity of competition, the ability of the organization to be positioned against its rivals and affect the profitability of the company (Pulaj \& Kume, 2014).

Despite growing attention and extended literature, the competitiveness or competition remains a concept not clearly define, because there is no single definition for it. According to Waheeduzzan and Ryans (1996), the competition is a cause or an instrument to achieve objectives. Flanagan et al., (2007) show in their studies that understanding the competition belongs to the "spectators' eyes", who could be any of the internal or external stakeholders (Flanagan et al., 2007). Man et al. (2002) suggest defining the competition concept through four of its features such as: focusing on longterm performance, the continued control of resources and capacities, the competitive position of the firm toward other firms and dynamism processes to generate profits). Another definition about this concept given from Lu (2006) shows that: "Competition as a widespread concept is like the law of the jungle to survive in the market and outperform the rivals". The traditional financial indexes such as profitability, productivity or market share remain the best indicators to measure the level of competitiveness in an industry.

Finally, we can say that many authors are involved in debate about the competition by bringing a comprehensive framework on dimensions and features that characterize competition such as: definitions ' diversity, diversity of measures and indexes, application fields, dynamism and continuing process.

Despite there is no unique definition on competition, this concept is an important part of management analysis together with other indicators such as profitability, market share or productivity (Pulaj \& Kume, 2014).

Another model to analyze the level of competition is the industry analysis model proposed by Porter considering five forces: competitive rivalry, threats of new entrants, substitute products and power of suppliers and buyers. Due to the five forces model, businesses can evaluate their industry, forecast and conceptualize their positions compared to other companies.

Some important questions need to be answered during the industry analysis: 
How much one industry is attractive and profitable? Why some industries are more attractive than others? Why some firms within an industry are more profitable than other in the same industry? How the industrial variables influence the organizational performance?

\subsection{Literature review and industry environment analysis}

There are a lot of factors influencing the company performance within an industry. If a company wants to analyze the potential industry's profitability and to define the nature of competition, competitive forces model helps on the way of gathering information and processing it.

Another value for which this model, is the opportunity it creates to managers thinking about the concrete situation, formulate strategies and serves as a starting point for other detailed analysis. The interaction of these competitive five forces is a constant and detailed study to the success of a company.

Intensity of competition. It is important for firms to increase their awareness and understanding of the degree of competition within the industry (Pulaj \& Kume, 2014). In this way, competitors test each other's strengths and opportunities to gain continuously the right competitive advantage and dominate the market (Kume, 2010) in order to be long-lived and profitable in the market.

Threat of new Entrants. The number of companies is one of the main indicators meaning the concentration level. New entrants to an industry bring new capacity, the desire to gain market share and often substantial resources (Porter, 1979). They are potentially ready to enter the market and contribute to shape to the industry structure. The number of new firms, encouraged to enter in profitable industries, is high due to the attraction of high profits affecting the profitability of existing firms.

Among the first authors studied the entry barriers is Bain (1956), according his strategic thinking these barriers allowed existing firms to ensure high profits without encouraging new firms to enter the industry. The economies of scale and capital requirements accomplish his definition on entry barriers explaining the positive correlation with higher profits that existing companies provide. According to Stigler (1968) explains that the cost production is another entry barrier and should face from new entrants.

The views on entry barriers' concept have sparked much debate and further developments. Ferguson (1974) sees the entry barriers as characterizing factor which allows existing firms to set prices below marginal costs and ensure consistently high profits. Since 1975, with the evolution of the planning process and culminating achievement in the stage of strategic management and entrepreneurship theories, Hofer (1975) presented the barriers to entry as the main variable in the structure of the industry.

Later, the importance of entry barriers on the profitability of existing firms was the motive for their classification into two categories:

i. Entry barriers created as a result of the structural characteristics of industries, and

ii. Entry barriers created as a reduction of new firms by existing firms.

Despite the different definitions of entry barriers, it is important to identify the barriers that existing firms create and to what extent these barriers inhibit or encourage new entrants. Some of them are: economies of scale, capital requirements, access to distribution channels, cost disadvantages independent of size, government laws, product differentiation, switching costs, expected reaction, customer loyalty, network effect.

The bargaining power of suppliers is described as another factor which affects the industry structure. Suppliers of all resources or factors of production can be potentially a source of power on firms when the supply industry is dominated by a few numbers of suppliers. Generally, powerful suppliers can reduce the profitability in an industry, but specifically it depends on industry's features and other potential factors such as: supplier switching costs, presence of substitute inputs, the high level concentration of supplier, the opportunity of vertically integration with the company reducing in this way the cost of inputs.

The bargaining power of buyers. According to Porter (1980), the customers influence the firms within an industry to impose low prices. The power of buyers depends on the following potential factors: the number of buyers and their concentration, the level of information and bargaining leverage, the cost to change the supplier, the standardization of the required product and the total amount of trading.

Threat of substitutes. The existence of substitute's product is the availability of a product that consumer can purchase instead of the industry's product. Customers often use the substitute product when their propensity to substitute is related with the following potential factors: relative price, number of substitute products available and buyer switching costs, perceived level of product differentiation.

Under the light of this factors analysis, the sum of the competitive forces impacts determines the intensity of 
competition. The profitability and attractiveness of the industry stay in an inverse relation with the capacity of each force included in Porter's model. The greater the power of competitive forces the smaller is the expected profitability (Pulaj\&Kume, 2016).

\section{Methodology}

In this study it is aimed to explain the relationship between industry forces and organizational performance. The current study considers a sample of construction companies registered in Vlora's region. The companies were asked to express their assessment on variables used to analyze the industrial environment. Each used variable was expressed by an interpretative statement to increase the level of understanding and facilitate the completion of the questionnaire. The variables and their sub variables used in the questionnaire are:

$\mathrm{P}_{1}-$ dynamics and structure of the market. Based on the market's definition, as the place where the buyer and seller express their desire and the ability to buy and/or sell a product or service, the group of variables classified under market structure include: market size, opportunities to create a goodwill, customers distance from firm, customers distribution, seasonality demand changes, the intensity of price negotiation, market transparency.

The sample population is taken from the construction industy. The construction industry like the others industries which operates in a dynamic and complex external environment (K'Obonyo, 2004; Davis et al., 2009), needs to analyze factors which measure the extent and frequency of industry changes. Variables included in the dynamics of the industry and its market are: the real market growth, the expected market growth, the rate of leaving the industry, the degree of uncertainty about future developments, changing customers' needs and the rate of new entrants in the industry.

$\mathrm{P}_{2}$ - Competitive dynamics and variables that are included in this group refer to the company experiencing changes in organizational structure, cost structure, new investments planning, being influenced by existing companies and new entrants ones. Some potential variables are: the opportunity of change influenced from the organizational structure, the degree of change due to legislative restrictions, the degree of change due to the cost structure, existing firms severe responses, introduction and continuous improvement of the products/services and investment in new assets.

$\mathrm{P}_{3}$ - Rivalry competitive. One of the main forces in Porter's model on the industry analysis is competitive rivalry. The potential variables in this study which explain the high level of competition within the industry are: concentration rate, number of competing firms, product heterogeneity, heterogeneity of industry members, labor cost, and diversification rate.

$\mathrm{P}_{4}$ - Company's dependence refers to all the variables that create dependence from production inputs, customers and external environmental factors. The variables that explain the dependent relationship of the company are: dependence on customers, dependence on suppliers, dependence on key employees, dependence on legislative changes, dependence on business cycle and dependency on exit barriers.

$P_{5}$ - Barriers to entry. Seen in the context of the industry, the entry barriers variables play an important role in attracting or deterring new entrants. However, it is difficult to assess whether an entry barrier has a positive or negative impact without full information from the company. The potential variables included under this category are: the economies of scale, capital and initial investment, acessibility of communication and distribution channels, customers' attitude and loyalty, vertical integration and legal barriers.

Dependent variables. Measuring the performance of the company remains a very controversial issue, referring to the criteria or measurement units. It should be notice that the performance of each company may be analyzed from the realization of its stakeholders' interests (Smith \& Reece, 1999). The attitude of companies toward the dependent variable (performance) is measured from the overall performance of the company and the success achieved. It was asked to assess the performance of the company during the last 3 years, on the basis of Likert's scale from $1-5(1=$ is deteriorated significantly; 5 = has improved significantly).

To examine the relationship between the industry forces and firm performance, a cross-sectional research was adopted through the data collected from the questionnaire during 2012-2015 periods. The analysis of multiple regression was performed which enable us to assess observations belonging to particular groups of variables, such as industry forces and firms performance. The research model is presented as:

Performance $_{i}=\alpha_{i}+\beta_{1}$ (Dynamics and structure of the marketij) $+\beta_{2}$ (Competitive dynamicsij) $+\beta_{1}$ (Rivalry competitive $\left.e_{i j}\right)+\beta_{4}\left(\right.$ Company's dependence $\left.{ }_{i j}\right)+\beta_{5}\left(\right.$ Barriers to entry $\left.{ }_{i j}\right)+\varepsilon_{i}$

- $\quad$ where the dependent variable Performance $i$ refers to the performance of firm $i$,

- the independent variable Dynamics and structure of the marketij refers to the perception of the market's dynamics according the firm $i$ for the sub-variable $j$ such as real and expected market growth, changes in demand as a result of industrial leaving rate, the uncertainty about future developments, changing customers needs and the rate of new entrants in the industry, 
- the Competitive dynamics refers to the competitive actions among firms competing within a particular industry, including changes in organizational structure, cost structure, new investments planning, being influenced by existing companies and new entrants ones,

- the Rivalry competitive variables refers to the intensity of competition for the firm $i$ explaing throught subvariable $j$ such as concentration rate, number of competing firms, product heterogeneity, heterogeneity of industry members, labor cost, gross profit, diversification rate,

- the Company's dependence refers to all the sub-variables $j$ that create dependence from production inputs, customers and external environmental factors and

- Barriers to entry refers to the variables $j$ that attract or deter new entrants,

- $\quad$ And $\alpha_{i}$ is the constant term, $\varepsilon_{i}$ is the error term.

It is used linear regression analysis to test the relationship between performance and industry forces explained with sub variables given to explain each of the above competitive forces. The gathered data have been evaluated in SPSS program. Statements related with the main variables used in the survey have been subjected to factor analysis classified by reliability test (Cronbach Alpha).

\subsection{Sample size and demographic characteristics}

In the study, it has been involved all the construction companies that do business activity in Vlora's region and in their construction projects portfolio include: infrastructure projects, residential buildings (living apartment and villas), industrial constructions and other buildings such as hospitals, universities, government buildings, etc. The data are collected through a structured questionnaire. The questionnaire includes sections which assess the impact of competitive forces on company`s performance. The survey is conducted mainly in Vlora city and randomly in Himara and Orikum.

Table 1 presents the distribution of companies according the year of creation. It is noticed that the participated companies have different longevity beginning from 1992. Almost $32.7 \%$ of sample had over 10 years in this industry till the year 2001. It is noted that the period between the years 2000-2008 marks the highest number of registered firms due to the development of construction industry and the highest number of building permits approved in the district of Vlora. Weighting the life of surveyed firms, we see the average lifespan in the industry is relatively 7.7 years because of the high number of registered firms in recent years as a result of inducement that offered the industry expressed at high profit rates. The distribution of firms by year of creation is given in the table below:

Table 1: Distribution of firms by year of creation

\begin{tabular}{|c|c|c|c|c|c|c|c|}
\hline Year & Frequency & Percent & Cumulative percent & Year & Frequency & Percent & Cumulative percent \\
\hline 1992 & 1 & 0.9 & 0.9 & 2003 & 8 & 7.3 & 42.7 \\
\hline 1993 & 2 & 1.8 & 2.7 & 2004 & 3 & 2.7 & 45.5 \\
\hline 1994 & 2 & 1.8 & 4.5 & 2005 & 11 & 10.0 & 55.5 \\
\hline 1995 & 4 & 3.6 & 8.2 & 2006 & 10 & 9.1 & 64.5 \\
\hline 1996 & 3 & 2.7 & 10.9 & 2007 & 12 & 10.9 & 75.5 \\
\hline 1998 & 5 & 4.5 & 15.5 & 2008 & 13 & 11.8 & 87.3 \\
\hline 1999 & 3 & 2.7 & 18.2 & 2009 & 7 & 6.4 & 93.6 \\
\hline 2000 & 7 & 6.4 & 24.5 & 2010 & 5 & 4.5 & 98.2 \\
\hline 2001 & 9 & 8.2 & 32.7 & 2011 & 2 & 1.8 & 100.0 \\
\hline 2002 & 3 & 2.7 & 35.5 & Total & 110 & $100 \%$ & \\
\hline
\end{tabular}

Table 2 presents the distribution of companies according the employees number. 43 companies $(39.1 \%$ of total) have fewer than 10 employees. The majority of the sample, approximately $55.5 \%$ of the companies have between $10-49$ employees and only 5.5\% of companies declared the number of employees between 50-249 employees. One of the main reasons for the high number of construction firms, registered as a small and the medium companies is the subcontracting process of works by other companies that offer specialized services.

Table 2. Distribution of firms by number of employees.

\begin{tabular}{|c|c|c|c|}
\hline Employees number & Frequency & Percent & Cumulative percent \\
\hline $1-9$ employees & 43 & 39.1 & 39.1 \\
\hline $10-49$ employees & 61 & 55.5 & 94.5 \\
\hline $50-249$ employees & 6 & 5.5 & 100.0 \\
\hline Total & 110 & 100.0 & \\
\hline
\end{tabular}


According the data gathered from the questionnaires, the geographical distribution of the companies is mainly in Vlora, Orikum and Himara Municipalities, covering all areas where construction industry had the higher development period, including both urban area and coastline. Most of the firms perform their activities in Vlora, while only $8.2 \%$ in Orikum and $2.7 \%$ in Himara. Discussing the distribution of companies by the construction projects included in their portfolio, it is noted that most of the works and projects, nearly $86.4 \%$ of the sample size, belong to the private sector such as residential, commercial and industrial construction (houses and apartments). Only 13.6\% of the projects belong to public sector such as infrastructure (roads, tunnels, bridges, airports) and institutional constructions (schools, hospitals, etc).

\section{Analysis}

According to the theory of competitive forces (Porter, 1980) and many other researchers who refer to industry analysis, it is noted that the positive or negative impact on sales growth, return indexes and overall performance, is related to the dynamics of environmental factors where the company operates.

For this purpose, it has been developed a multivariate analysis indicating the proper correlation and the impact of industry forces on the dependent variables, measured by overall firm performance. All the factors with a significant correlation ( ${ }^{*} p<0.05$ level) were analyzed through a multiple regression analysis to reveal their impact on the overall firm performance (see Table 3).

Table 3. Selected independent variables with higher correlation with dependent variable/overall performance of the company ( $\mathrm{N}=110)$

\begin{tabular}{|llc|}
\hline Variables & & $\begin{array}{c}\text { Overall } \\
\text { performance }\end{array}$ \\
\hline $\begin{array}{l}\text { Distance to clients. All the firms in the industry generally compete on national } \\
\text { level and not only in local and regional level }\end{array}$ & Pearson Correlation & $-.202^{*}$ \\
\hline Continuous improvement of the products/services & Sig. (2-tailed) & .035 \\
\hline Seasonal change of demand. & Pearson Correlation & $.289^{* *}$ \\
& Sig. (2-tailed) & .002 \\
\hline Dependence on exits from industry. A large number of firms have to close down & Pearson Correlation & $.121^{*}$ \\
their businesses leaving the industry. & Sig. (2-tailed) & .021 \\
\hline Uncertainty degree about future development. The demand varies and it is a & Pearson Correlation & $.028^{*}$ \\
\hline difficult to forecast the development on the industry. & Sig. (2-tailed) & $-.216^{*}$ \\
\hline Dependence on suppliers & Pearson Correlation &. .374 \\
\hline Legislation. The construction industry depends to a large extent on legislative & Sig. (2-tailed) & .044 \\
\hline changes. & Pearson Correlation & $-.291^{*}$ \\
\hline Dependence on business cycle. The demand of products and services varies & Sig. (2-tailed) & .034 \\
\hline strongly from business cycle. & Pearson Correlation & $-.191^{*}$ \\
\hline Dependence on exit barriers. All large firms have to stay in the industry even if & Pearson Correlation & .048 \\
\hline demand and the profits strongly decrease. & Sig. (2-tailed) & $.199^{*}$ \\
\hline New assets investments & Pearson Correlation & $.260^{* *}$ \\
\hline Number of competing companies & Sig. (2-tailed) & .006 \\
\hline
\end{tabular}

First, to assess whether the multiple regression model is valid or not, it is used ANOVA analysis. According generated values in Table 4, it is evident that the established model is valid. In our model, the $F$ value is $4046>1.89$ ( $F$ critical value $(11,98)=1.89)$ resulted significant, $p=0,001$ is less than 0.05$)$. 
Table 4. ANOVA analysis of industrial variables and their impact on dependent variable "Overall firm performance evaluation"

\begin{tabular}{|c|c|c|c|c|c|c|}
\hline \multicolumn{2}{|c|}{ Model } & Sum of Squares & df & Mean Square & F & Sig. \\
\hline \multirow{3}{*}{1} & Regression & 21.292 & 11 & 1.936 & 3.263 & $.001^{\text {a }}$ \\
\cline { 2 - 7 } & Residual & 58.126 & 98 & .593 & & \\
\cline { 2 - 7 } & Total & 79.418 & 109 & & & \\
\hline
\end{tabular}

a. Predictors: (Constant), dependence on business cycle, legislation, number of competing firms, continuous improvement of the products/services, investment on new assets, dependence on exits from industry, customers distribution and distance from the company, the degree of uncertainty on future development, dependence on suppliers, dependence on exit barriers, seasonal change of demand.

b. Dependent Variable: overall firm performance

Regression analysis table shows the interaction of industry variables and dependant variable measure by overall performance of the company. As it is shown from the regression analysis, only some of the regression coefficients have their $p$ value acceptable $(p \leq 0.05)$.

Table 5. Industry variables` coefficients and their impact on "Overall firm performance"

\begin{tabular}{|c|c|c|c|c|c|}
\hline \multirow[t]{2}{*}{ Independent variable } & \multicolumn{2}{|c|}{$\begin{array}{l}\text { Unstandardized } \\
\text { Coefficients }\end{array}$} & \multirow{2}{*}{$\begin{array}{c}\begin{array}{c}\text { Standardized } \\
\text { Coefficients }\end{array} \\
\text { Beta }\end{array}$} & \multirow{2}{*}{$\begin{array}{c}T \\
\text { value }\end{array}$} & \multirow[t]{2}{*}{ Sig. } \\
\hline & $B$ & Std. Error & & & \\
\hline (Constant) & 3.535 & .686 & & 5.152 & .000 \\
\hline $\begin{array}{l}\text { Distance to clients. All the firms in the industry generally compete on } \\
\text { national level and not only in local and regional level }\end{array}$ & -.141 & .061 & -.209 & -2.300 & .024 \\
\hline $\begin{array}{l}\text { Uncertainty degree about future development. The demand varies and it } \\
\text { is a difficult to forecast the development on the industry }\end{array}$ & -.146 & .074 & -.193 & -1.981 & .050 \\
\hline $\begin{array}{l}\text { Dependence on exit barriers. All large firms have to stay in the industry even if } \\
\text { demand and the profits strongly decrease. }\end{array}$ & .078 & .062 & .123 & 1.262 & .210 \\
\hline New assets investments & .108 & .071 & .142 & 1.510 & .134 \\
\hline Number of competing companies & -.198 & .096 & -209 & -2.069 & .041 \\
\hline Continuous improvement of the products/services & .171 & .069 & .233 & 2.479 & .015 \\
\hline Seasonal change of demand & .129 & .081 & .168 & 1.587 & .116 \\
\hline $\begin{array}{l}\text { Dependence on exits from industry. A large number of firms have to close } \\
\text { down their businesses leaving the industry. }\end{array}$ & .111 & .078 & .131 & 1.424 & .158 \\
\hline Dependence on suppliers & -.186 & .072 & -.256 & -2.568 & .012 \\
\hline $\begin{array}{l}\text { Legislation. The construction industry depends to a large extent on legislative } \\
\text { changes. }\end{array}$ & -.013 & .066 & -.019 & -.197 & .844 \\
\hline $\begin{array}{l}\text { Dependence on business cycle. The demand of products and services varies } \\
\text { strongly from business cycle. }\end{array}$ & -.049 & .076 & -.065 & -.641 & .523 \\
\hline
\end{tabular}

Source: Results obtained by the authors.

Based on the analysis of multiple regressions, the variables that must stay in the model and have a negative impact on the performance of the company are: distance to customers/ clients, the degree of uncertainty about future developments, the large number of firms competing, the need for specialized product and dependence on suppliers. This indicates that the performance of companies and the success rate is negatively affected by these factors.

According the public procurement and bidding process, the companies have right of access in this process regardless the where a project is implemented. The same phenomenon occurs also in the case of investments in 
residential building projects while different firms invest in cities that represent attractiveness due to demographic or economic development, increasing competitive rivalry between the existing companies in this area. Another factor negatively influences the construction industry, is the uncertainty about future developments. This industry is experiencing a period of stagnation and the housing market seems to be saturated. Despite the high number of apartments built, which according to INSTAT statistics, urban areas seems to have an unfavorable distribution and not well studied by the builders. These factors combined with the difficult economic and financial situation that businesses are experiencing, increase the uncertainty on the future development. The same financial meltdown due to: modest demand for apartments, a high-margin profit of landowners, the high cost of borrowing, the lack of liquidity, administrative bureaucracy and the accumulated debt that public administration institutions owe Albanian construction companies for public works. It has caused dependence on suppliers during the entire value chain of this industry.

Among the factors which have a positive impact on firms' performance is the ability to offer continuous improvement of the products/services, modified and adapted to the characteristics of clients (public sector or private sector) and creates a differentiation from other competitors in the market.

The relationship between independent variables and the dependent one is given between the regression equations:

"The overall firm performance" ' $=3535-0209$ (distance to customers) - 0.193 (uncertainty degree about future development) -0209 (number of competing firms) +0233 (Continuous improvement of the products/services) - 0.256 (dependence on suppliers).

\section{Conclusions}

This study examined the effects of industry forces on firm performance using several sub-variables that explain each of industry forces according Porter's Model. The study is conducted using data from the 2012 to 2015 period. The regression analyses showed a statistically significant negative relationship between firm performance and distance to customers, uncertainty degree about future development, the number of competing firms and dependence on suppliers.

The finding that there is a positive relationship between performance and continuous improvement of the products/services variable shows that the product served in this industry needs more improvement related with quality, product's attributes and location which makes a competitive advantage for construction companies. These results indicate that firms in the sample did not obtain only scale economies to enhance their performance but there are several factors indicating the performance.

So, the degree of attractiveness and profitability of the industry depends on the impact of competitive forces, the level of the opportunities and threats presented by the direct impact on firm performance.

\section{References}

Bain, J. S.(1956). Barriers to New Competition, Cambridge, Harvard University Press.

Balkytè, A \& Tvaronavičienè, M. (2010). Perception of competitiveness in the context of sustainable development: facets of "sustainable competitiveness". Journal of Business Economics and Management, Vol 11(2), pp. 341-365.

Davis, J.P., Eisenhardt, K.M., Bingham, C.B.(2009) Optimal Structure, Market Dynamism and the strategy of simple rules. Administrative Science Quarterly, Vol 54, pp. 413-452

Ferguson, J. M. (1974). Advertising and Competition: Theory, Measurement, Fact.cambrige. Ballinger Publisher

Flanagan, R., Jewell, C.A., Ericsson, S., \& Henricsson, P. (2005). Measuring construction competitiveness in selected countries, Final Report. The Research Team at the University of Reading.

Hofer, C. (1975). Toward a contingency theory of strategy. Academy of Management Journal, December, pp. 784-810.

K'Obonyo, P. (2004) Strategic Orientation and Export Behaviour of Small Enterprises: a Conceptual Synthesis in Entrepreneurship Research and Development in Africa: Achievement, Challenges and Future Prospects. Erasmus S. Kaijage and Lufumbi J. Mwaipopo Eds. Mkuki na Nyota Publishers Ld. Dar es Salaam, Tanzania

Kume, V. (2010). Menaxhimi strategjik. Teori, koncepte, zbatime. Tirane.

Lu, W. (2006). A system for assessing and communicating contractors' competitiveness. Doctoral dissertation, The Hong Kong Polytechnic University, China.

Man, T.W.Y., Lau, T., and Chan, K.F. (2002). The competitiveness of small and medium enterprises: A conceptualization with focus on entrepreneurial competencies, Journal of Business Venturing. Vol 17 (2), pp.123-142.

Porter, M.E. (March-April 1979) How Competitive Forces Shape Strategy, Harvard Business Review.

Porter, M. (1980). Competitive Strategy: Techniques for Analyzing industries and competitors. New York

Pulaj, E and Kume, V. (2014). Basic Tools and Frameworks for Analyzing and Understanding Competitiveness Within the Industry. European Journal of Sustainable Development Vol 3(1), pp. 47-56, Doi: 10.14207/ejsd.2014.v3n1p47 
Stigler, G. (1968). The Organization of Industry, Chicago, University of Chicago Press,

Waheeduzzan, A.N.M., \& Ryans, J.K. (1996). Definition, perspectives, and undërstanding of international competitiveness: a quest for a common ground. Competitiveness Review: An International Business Journal incorporating Journal of Global Competitiveness. Vol 6(2). pp.7-26 